\title{
Philosophical Values of Pancasila on the Intellectual Property Rights Regulation in Indonesia
}

\author{
Andy Usmina Wijaya ${ }^{1} \quad$ Sekaring Ayumeida Kusnadi ${ }^{1} \quad$ Farina Gandryani $^{1}$ \\ Fifin Dwi Purwaningtyas ${ }^{2}$ \\ 1.Faculty of Law, Wijaya Putra University \\ 2.Faculty of Psichology, Wijaya Putra University
}

\begin{abstract}
Legal pluralism applied in Indonesia is expected to be able to build its own national law system based on the custom and cultures characteristics as a reflection of Indonesian nation's soul (volkgeist). Indonesia custom and cultures adhered to the view of property acknowledgement, and also had social function. Intellectual Property Rights (IPR) is a part of property rights which had individual characteristic to monopolize proprietorship rights of intellectual works. IPR regime characteristic is completely different from Indonesia's nation characteristic, which made Pancasila as life philosophy and nation's ideology by prioritizing the balance between rights and social function. The type of research used in this study is legal normative research, with legal approach, conceptual approach and philosophical approach. As Indonesia's philosophy of life, Pancasila contained the values of nation's soul and legal ideals of Indonesia. As the legal ideals of Indonesia as well as staatsfundamentalnorm on the legislation hierarchy, the basic values of Pancasila must underlie and animate IPR legal development in Indonesia. Divine value, human value, unity value, deliberation value and social justice value are basic values that should animate the development of legal IPR in Indonesia.
\end{abstract}

Keywords: IPR, Staatsfundamentalnorm, Pancasila, Social Function

DOI: $10.7176 / \mathrm{JLPG} / 113-04$

Publication date:September $30^{\text {th }} 2021$

\section{Introduction}

IPR is a right originated from the creative activity of humans' intellectual ability that is expressed to public in various forms such as technology, knowledge, art and literature, which has benefit and is useful for humans, and also has economical values. As property rights of opus, initiative or creations of humans' intellectual abilities can be recognized that the creator may control it for purposes that benefit him/her.

Since the promulgation of Act Number 6 Year 1989 of Patent (Patent Law), IPR is a legal instrument that reflects monopolistic character which objects mutual cooperation values. However, Presidential Decree Team 34 State Secretariat of the Republic of Indonesia through Patent Act at that time, could harmonize legal norms of patent rights with the national interest. The preamble of Patent Act puts down a sentence stated that the Republic of Indonesia is a state law based on Pancasila and Constitution 1945, aimed to create fair and prosperous society that is materially and spiritually evenly distributed. Along with the development of time, Pancasila is not written anymore in the preamble of various legislations which related to the IPR protection.

IPR is an individualistic regime to monopolize technology and is beneficial to protect investment, which is completely different from the characteristics of Indonesian people. As a right, IPR cannot be separated from economic problem since it is identical with commercialization of intellectual works. Substantially, the regulations of IPR sourced in the concept of individualistic and capitalistic society. By this individualistic system, it disabled the development of acknowledgement to society rights collectively as developed in socialist economic states. Moreover, the developed system in Western States is impossible to protect indigenous people's rights of their intellectual properties, which generally are not owned individually as in Indonesia. The objection to recognize the collective rights of the people by developed countries is essentially a manifestation of the developed countries' desire to continue dominating developing countries in relation to the proposed form of intellectual property protection. The developed countries imposed Western concept which is individualistic in protecting the communalistic rights of indigenous people.

Pancasila admitted ownership rights as a part of legal ideals (rechts idee) of the Republic of Indonesia in achieving one of its national purposes, which is to create public prosperity. IPR as private property right is admitted in Indonesia based on the values of Pancasila, so it cannot be taken arbitrarily. Therefore, IPR as an exclusive right that legalized monopoly is also limited by law (limitation and exception), or has a social function in the Indonesian context.

To this time, law and regulations in Indonesia that related to IPR have not represented the philosophy values of Indonesian nation's soul. The law and regulations are still representing individualism system developed by countries which hold liberalism and capitalism. This matter is not in accordance with the characters of life of the nation and state in Indonesia that adhered to communal collective ideology. For this reason, it is necessary to develop IPR law and regulations in Indonesia which are imbued with the philosophical values of Pancasila. 
In connection with the background above, the problem to be taken is the legal development of the regulation of intellectual property rights legislation in Indonesia based on the philosophical values of Pancasila.

\section{Research Method and Approach}

This article is the result of study using the normative legal research method, it is a method to identify concept and legal principles and to break legal issues, and at the same time to provide prescriptions on what should be done. ${ }^{129}$ In examining legal issues, legal theory is needed. The uses are, first, to reveal the dark corners of a legal system and to point out the way of valuable constructive change regarding the elements of legal concepts. Second, legal theory helps to answer basic questions of legal system which essentially is the knowledge of system, it has different meaning than to know how to run a system. ${ }^{130}$ The theory used in this study is legal development theory. The essence of legal development theory is to place law as a medium of society and legal renewal as a requisite system for Indonesia which is developing. This theory is adopted and modified from Roscoe Pound theory known as "law as a tool of social engineering" concept. However, according to Mochtar Kusumaatmaja, the phrase "tool" is perceived as a means or instrument to build society not as a tool to modify the society. ${ }^{131}$ As for the approaches used in this study are statute approach, conceptual approach and philosophical approach.

\section{Discussion}

\subsection{Pancasila in Philosophical Perspective}

Talking about the philosophy of Pancasila, it cannot be parted from the understanding of Pancasila as the fundamental philosophy and the people of Indonesia's view of life that is contrary to the western philosophy. Western philosophy is contradictory to individualism that convinced to the belief that humans are created free and equal. It is clear that this matter is contradictory to the philosophy of Pancasila, which starts from the belief that humans are created in togetherness w each other.

The philosophy of Pancasila is not only based on the thought of a philosopher, but also the result of the thinking process of the people of Indonesia. Based on the life experiences of the People, valuable experiences is obtained to achieve a better life in the future. The experiences contain values and concepts which are crystalized into a view of life to be applied in facing nation's issues. The thoughts of values and basic concepts in Pancasila is formulated in every view of life of the Indonesian people.

As the Indonesian' view of life, Pancasila has been formulated in the unified set of the five principles of Pancasila. Pancasila is placed in the Prefatory of Constitution 1945 as the philosophical foundation that underlay and animated all provisions written in Constitution 1945. Therefore, Pancasila underlies and should animate the state life in Indonesia, including the activities that determine and implement legal politics.

The Pancasila view of life is guided by the belief that the universe and all the things inside it as a harmoniously interwoven whole created by the One Almighty God. Human comes from God and the ultimate goal of his/her life is to return to the original source. Thus, piety to the One Almighty God is the obligation of every human being. In accordance with their nature, humans are created by the One Almighty God as social beings. It means, based on their nature, the existence of humans are alive in their togetherness. In this togetherness, every human has a unique personality and this matter creates differences among them. All the differences of unique personalities create a unity known as humanity. Because of that, the existence of human beings in their togetherness show the character of oneness and congruity, that is humanity in different and unique individuals. Otherwise, togetherness shows the nature and personality of each unique individual among the differences in united humanity. So that there is different in unity.

Bhinneka Tunggal Ika formulated the first principle in determining the position of human beings in a society. Human is a subject that has unique nature. The nature of this personality is undeniable without going through its nature. It means that every human being should acknowledge and accept the existence of that personality to become human. Which means, to keep their existence as society, they should acknowledge, maintain and protect every personality.

The characteristic of relationship between humans and their community based on and inspired by affection. Affection that inspired humans' relationship is brought by the nature of togetherness, which ultimately sourced to The God Almighty. Therefore, Pancasila view of life is also known as kinship view of life based on the notion that there is no human exists and lives apart from the relationship of togetherness with other humans in the unified society, as well as awareness and recognition that humans depend on their environment.

\footnotetext{
${ }^{129}$ Peter Mahmud Marzuki, 2005, Legal Research, Kencana Prenada Media Group, Jakarta, 2005, pg. 141.

${ }^{130}$ Richard A. Posner, Frointers of Legal Theory, Harvard University Press, 2001, pg.14-15.

${ }^{131}$ Romli Atmasasmita, Integrative Legal Theory, Legal Development Theory and Progresive Legal Theory Reconstruction, Genta Publishing, Yogyakarta, 2012, pg. 88
} 


\subsection{Philosophical Values on Intellectual Property Rights}

Humans as intelligent beings are part of God's law on humans' life, so humans should be able to distinguish between good and bad. Therefore, every individual has natural right to the full exploitation on ideas, so that an unauthorized use by another party without compensation is considered as theft. These properties are personal and exclusive and thus the community and State based on the moral obligation should acknowledge and protect the rights. ${ }^{1}$

On the protection of IPR there are 2 (two) influential philosophers, they are John Locke and Friedrich Hegel. IPR concept according to John Locke and Hegel comes from Natural Law Theory which sourced from morality in reference to goodness and badness. Natural rights are derived from the real nature for tangible materials. Both of them did not directly give the conception of IPR. It means that the common concept and justification of wealth have been dominated by tangible properties. ${ }^{2}$

John Locke in his book The Second Treatise of Government on 1689 taught the concept of ownership with preposition that effort or manpower belongs to someone and when the person properly produced an object out of the general usage, the person then combined the efforts on the matter as an object. If someone else took the object, it would be considered as stealing his/her effort since the first person has attached the effort to the available object. It is detrimental for the first person, so others should never harm him/her. For this reason, others have an obligation to let the first object possessing its property, on the other hand, the person with his/her labor is limited by two things, what existed is enough and what left is good for others.

Moreover, John Locke stated that considering humans are equal in status naturalis, so the obligation of one another is equal as there are 2 (two) keys of freedom rights, which are:

a. Everyone has the right of freedom to do an effort as his/her wish;

b. Everyone has the right of freedom to use the earth and all its fruits that God provide to mankind.

Both freedom rights mean that in the natural law, no one can sue others for the use that is not harmful to individual effort or to the community. However, with his/her action, a person is not allowed by his/her right to harm other's right. A person has no right to harm other people or to obstruct their access to the society. John Locke emphasized on the effort to create intellectual creation which are the rights that must be rewarded and directly implied to economic compensation.

But John Locke's view is different from Friedrich Hegel's as written on his book entitled The Philosophy of Right on 1821 and The Lectures on the Philosophy of History on 1820 explained the concept of Right, Ethic and State. Hegel developed a concept of ownership in relevant to the existence of personality. Hegel explained that ownership rights which are associated with personality or self-identity (the Personality Theory) according to him, desire is free inside and for him/herself. As an abstract conception, someone must provide him/herself an external space out of freedom so that the abstract conception can turn into idea. Properties, among other things, are media where a person can objectively suggest personal and single desire.

In the end, according to Hegel, personality is free and the personality that started when it had its own knowledge which is not being interfered by a limitation. It is a universal matter, but has not enough freedom, so that personality should achieve some concrete form of its existence in the world. This is the entrance to the wealth. The fusion of mental, talent, knowledge and artistic skill are called as inner ownership, which when externalized, it became something that has legal ownership. It is emphasized by Hegel that someone must interpret his/her freedom on external space to form an idea and it is the beginning of personality as a whole that is still abstract as the determination of absolute and unlimited will. It will interact with external world by various activity stages. Mental process, as confession, classification, explanation and remembrance can be seen as taking over the external world through cogitation. This action is the first step on the ongoing struggle for selfactualization.

Hegel maintained conception about property by differentiate between option convenience function and the institution of wealth inherently on the level of abstract right from optimal evolution in the life ethics. Every discussion on freedom must not be started from individual concept or individual awareness, but from the essence of self-awareness. Human must realize the scope of meum and tuum, there is no other way for a person to distinguish himself/herself abstractly from the existing world and other person. This matter is the prima facie justification of fascinating wealth institution for their inherent quality. Personality as a power that gave ability to identify itself and interpreted its freedom externally to exist as an idea. For this reason, according to Hegel, personal wealth on a specific stage should be a personal matter and personal property as universal institute. It became the base of IPR justification. ${ }^{3}$

According to Hegel, there is something deeper in wealth than just human's behavior. The importance of wealth as a way to build, develop and understand our personality, expression that we would control and also

\footnotetext{
${ }^{1}$ Abdoel Gani, Philosophy of Law, Law Study Lecture, Postgraduate Program of Doctorate Law Study Airlangga University, Surabaya, 2001 2001

${ }^{2}$ Mathew Fisher, Fundamental of Patent Law, Hart Publishing, Oxford, 2007, pg. 66

${ }^{3}$ Rahmi Jened, Intellectual Property Rights: Abuse of Rights, Airlangga University Press, Surabaya, 2007, pg. 21
} 
decide the limitation between another individual and another property from the society and finally this matter is a way of how human would appreciate the personality of each individual through the valuation of IPR. Humans have the freedom to choose the wealth they wished to obtain and social function that they desired. Thereby, the real problem is the legal issue not the ethic issue, and as a result, court is needed to physicalize object of wealth. ${ }^{1}$

Hegel's concept established the capacity of someone's right together with ethics of life and the familiar divine feeling and established minimal moral standard. And at the same time, prevented inconsistent matters from the statement that a person owns his/her physique naturally and it is not a property. Abstract right, not from humans' naturally entity, but from the desire of freedom inside them and by themselves, that matter is an abstract conception. Property is an expression of desire as a part of personality and the matter created regulations for the next step.

Legal protection is usually limited and the reward on intellectual property is given to the power of right and society's reward, and depended on the thinkers' ability and society's tolerance to prevent imitation. According to Hegel, property as personal identification also gave advantage to society. Market segment is the judge through individual market tried to place and protect self-identity by voluntary property exchange that reflected individual desire. Society in this matter has limited right to prevent fair self-interest in the accumulation, possession and permission to his/her property. The society's needs would not justify the takeover of someone's wealth without proper compensation. ${ }^{2}$

Therefore, Hegel's theory completed Locke's by two reasons, first, IPR is the property related to creation that showed intellectual capacity and creativity of humans rather than just a consumption as stated by Locke. Second, Locke's interpretation on the theory that showed the logical sequence of IPR that humans from the beginning own physique, soul and their effort that subject to an unmastered desert became the beginning of Hegel's theory, that IPR is an abstract right for the reason of humans' existence.

On the contrary, Hegel clearly stated in his conception of the right of human is separated from individualism as stated by Locke, and Hegel's concept perfected Locke's. If Locke emphasized on the effort of creating an intellectual creation is the right that should be rewarded and the effort is directly implied on economic compensation, then, Hegel completed it by emphasizing that intellectual creation is a form of personality as abstract right as a reason of humans' existence and reward is not just economic compensation, but reaching wider and farther of the economy right appreciation and moral right acknowledgement.

\subsection{Pancasila as the Thinking Base of the Development of Intellectual Property Right Law in Indonesia}

To this time, Indonesia is still applied pluralism law on its legal system including customary law, civil law, common law and Islamic law. Customary law is a genuine law that was born and grown in the society of Indonesia. Civil law existed in Indonesia since the Dutch colonization that enacted its law system and influenced the codification of commercial law, criminal law and civil law. Furthermore, legal system of common law is applied in Indonesia through convention and international treaty where Indonesia is registered as member.

Seeing the existence of legal system applied in Indonesia could develop its own national law corresponded to the values that sourced from the society and the Indonesian nation. In another word, Indonesia's national law should reflect Indonesian nation's soul (volkgeist) that is Pancasila, as well as the development of Intellectual Property Right Law. The development of Intellectual Property Right Law must be based on Pancasila as the life and cultural values of Indonesia and as ideals (rechtidee).

In the development of Intellectual Property Right Law in Indonesia must be based on the value of nation's ideology, historical value, sociological values of Indonesian society, juridical values and philosophical values that cored in justice and verity of Indonesian's society. Pancasila is staatsfundamentalnorm on the legislation hierarchy in Indonesia. Pancasila as the main value that base the forming of law in Indonesia. The importance of putting Pancasila as basic value is caused by, first, Pancasila is placed as the legal foundation of the nation and state, which continues to color the pattern of law in Indonesia with five basic values which included Divinity value, Humanity value, Unity value, Deliberation value and Social Justice value. Second, Pancasila as the basic value will face various values such as capitalism, individualism, etc. Third, as the spirit in every law in Indonesia, Pancasila has not received an essential meaning from legal experts.

Of the five basic values, Pancasila has two main values which are religiosity value and communality value. Religiosity value means the availability of thinking concept that in the cosmic space of notion and law are always keyed to Divinity value by positioning God as the center in the dynamics of law in Indonesian society. Moreover, the meaning of communality value is the cosmic space that humans in Indonesia have realized that they cannot live alone but always in a community. Communality value combined with religiosity value formed a philosophy known as Pancasila.

Communal value of Indonesian nation has specific particularity in the form of diversity and togetherness.

\footnotetext{
1 Ibid, pg. 22

${ }^{2}$ J.W. Hariris, Alan Ryan, Property and Political Theory, Blackwell, London, 1986, pg. 81. also on Peter Drahos, A Philosophy of Intellectual Property, Dartmouth, Sydney, 1997, pg. 73-88. Rahmi Jened, Op.Cit., pg. 19
} 
Togetherness becomes dynamics since inside it there is cooperation for mutual assistance between individual and group that covers multicultural, multi-ethnics, multi-lingual and multi-religious. So that, the communal value is filled by acceptance process among various cultural elements, religions and the values that formed it. For this reason, it is appropriate to state that the communal value of Indonesian nation is the communal diversity or kebhinekaan communal. If it is associated with the existence of belief on Divinity value, then it can be stated as religious value of communal diversity. Religious value of communal diversity is generated from the legal philosophy value of Pancasila as staatsfundamental norm which in the end will form grundnorm that is constitution.

Pancasila in the Prefatory of Constitution 1945means that the values in Pancasila are the guidelines for the state in Indonesia. Pancasila as the view of life contains values which are the spirit or soul of Indonesian nation as the statement that Pancasila is the main ideas and legal ideals, the state is intended and aimed to actualize happiness and prosperity, peace and independence in the society of Indonesian nation. Ideas and concepts imply the values of Pancasila as the source of all legal sources in Indonesia, are the constitutional command. The materials used in the formulating the main ideas of Pancasila as written in the Prefatory of Constitution 1945 are the noble values that are internalized by Indonesian nation, and become a foundation that underlies the state life, even so Pancasila also contains universal basic values that are the most important at this time.

Pancasila is an open ideology as it has meaning that fundamental values of Pancasila is permanent, but then the explanation can be developed creatively and dynamically along with the development of Indonesian society. Pancasila has fulfilled the requirements as an open ideology as it contains three dimensions, they are the reality dimension that is extracted from the genuine values of Indonesian nation, idealism dimension that is believed to be the most precise and correct for Indonesian nation, and flexibility dimension that can adapt to the development of time. Moreover, Pancasila as an open ideology contains three level values, consist of basic value as written in the Prefatory of Constitution 1945, instrumental values which are the explanation of the basic values of legislation to be reviewed according to the development of time, and practical values in the form of real implementation of basic values and instrumental values.

The development of instrumental values of Pancasila should be done in economic sector, socio-cultural, politics and defense and security through systematizing elements of Pancasila as the ideology and making them as an integrated, coherent and consistent thinking system. Correspond to the character of Pancasila as the intellectual creation of philosophers that needs diligent handling. Pancasila that is the soul and guidance of life of Indonesian nation has been considered capable in bringing an independent, united and sovereign nation of Indonesia, although it has not fully achieved the stage of just and prosperous peaceful society.

IPR Law intended to give protection to intellectual creation against the act of piracy and counterfeiting. If we compared it to the essence of national development that is the development of Indonesian people as a whole and all Indonesian citizens, so the Personality Theory by Hegel who stated that valuation system is in line with IPR regime as the new ownership can be applied in Indonesia. Property is interpreted as what is perculiar or proper to any person that which belongs exclusively to one; In the strict legal sense, an aggregate of rights which are guaranted or protected by government; the word is also commonly used to denote everything which is the subject of ownership, corporeal or incorporeal, tangible or intangible, visible or invisible real or personal, everything that has an exchangeable value or which goes to make up wealth or estate. ${ }^{1}$

The concept of wealth based on Indonesian law, including object and legal relation (engagement) to obtain the object. Wealth is an object that belongs to someone and has economical values including goods and rights. Acknowledgement and protection of the wealth and the right attached on it based on the legal evidence. The definition of property rights is written in Article 570 of the Civil Code which stated that property right is the right to use the benefit of an object freely and to act freely towards an object as long as it is not in contradiction with the law or general regulation that is stipulated by the authority that has the right to determine and does not interfere with the rights of others by not reducing the possibility of dispossession for the sake of common interest based on the provisions of law and compensation payment.

Based on that provision, the rights of property in the Article is only valid for movable assets including the right to control freely, the right to use completely, and does not contradict the law. Pancasila admitted the existence of property rights as a part of legal ideas of the Republic of Indonesia in achieving one of national purposes that is to create public prosperity. IPR as private property right is admitted in Indonesia based on the values of Pancasila, so it cannot be taken arbitrarily and should be for a specific purpose. Therefore, IPR as an exclusive right that has monopoly character is limited by law, and has social function.

Culture and the view of life of Indonesian nation in the ideology framework on Pancasila Nation, still viewed and placed human beings as a whole body, which is humans in their nature as an individual is the creation of the One Almighty God or as the living creature and be a part of another humans community. As social beings, human personally lived in a togetherness environment with other humans and even the natural

\footnotetext{
${ }^{1}$ Rahmi Jened, Intellectual Property Law Interface and Rivalry Law, Rajagrafindo Rajawali Press, Jakarta, 2013, pg.4
} 
surroundings. Nevertheless, whatever the concept of harmony, aptitude or balance that surrounds life, the view and valuation to human beings as individuals have the same weight with their nature and dignity as social beings. ${ }^{1}$

The respect for humans as individuals as well as their effort of development and the creations they have produced, continued to gain a high place. In another word, the concept of respecting someone as the creation of The One Almighty God is still given a high place, even though it must be actualize in harmony and balance with the concept of humans as social beings.

Furthermore, IPR protection as a part of property right, written in Article 28 Letter H Constitution 1945 (amendment) which stated that every person deserves to have private property right and the right cannot be taken over arbitrarily by anyone else. On Article 28 Clause (4) specifically stated that every person has the right to present him/herself in fighting for his/her right collectively to build society, nation and the state. Based on this provision, it is seen that IPR protection according to Pancasila is not only admitting individual property rights, but also acknowledging collective property rights. It is in line with the existence of international understanding development of collective intellectual property, which includes genetic resources, traditional cultural expression or folklore and traditional knowledge.

In associated with IPR protection, the values of Pancasila at the philosophical level inhold fundamental values that should protect the Act which are listed in the preamble. Pancasila in the norms or rules level contains implementative values. Meanwhile, in the context of interpretation of the law or law findings by the judge in specific cases contain practical values that are socially justified as a characteristic of Pancasila which is different from other justice values.

\section{Closing}

IPR was born and developed in western states that adhered to individualism and capitalism, so that these characteristics are different from Indonesian nation characteristics that put Pancasila as philosophy of life, nation soul, nation's ideology and nation legal ideal. Pancasila acknowledges property right as part of legal ideals of the Republic of Indonesia in achieving one of its national purposes of actualizing public prosperity. IPR acknowledgement as private property right in Indonesia is based on the values of Pancasila, and the use is limited by law and has social function.

The development of IPR law in Indonesia must be based on, founded on and inspired by the fundamental values of Pancasila, which are the communal religious value of diversity (kebhinekaan). Indonesian communal values have unique characteristics in the form of diversity and togetherness with cooperation to work together between individuals and community that consist of multicultural, multi-ethnics, multi-lingual and multi-religion. So that, these communal values is filled by acceptance process among various cultural elements, religions and the values that formed it. This communal religious value of diversity is derived from the values of the legal philosophy of Pancasila as staatsfundamental norm that inspired the all the existing laws and regulations in Indonesia including IPR.

\section{Bibliography}

Derclaye, E. 2008. Intellectual Property Rights and Human Rights: Coinciding and Cooperating. Dalam Torremans, P. (Ed.). Intellectual Property and Human Rights: 136. The Netherlands: Kluwer Law Internasional

Friedman Wolfgang, Theory and Law Philosophy: Critical Study on Legal Theories (Composition I), Print out. 2, Raja Grafindo Persada, Jakarta, 1993

Granstrand, O. The Economics and Management of Intellectual Property: Towards Intellectual Capitalism, Edward Elgar Publishing Limited, Cheltenham (UK), 1999

Jened Rahmi, Intellectual Property Rights : Abuse of Rights, Airlangga University Press, Surabaya, 2007

, Interface Intellectual Property Law and Rivalry Act, Rajagrafindo Rajawali Press, Jakarta, 2013

, Interface Intellectual Property Law and Rivalry Act, Rajagrafindo Rajawali Press, Jakarta, 2013

Mahmud Marzuki Peter, Legal Study, Kencana Prenada Media Group, Jakarta, 2005

Mathew Fisher, Fundamental of Patent Law, Hart Publishing, Oxford, 2007

Mitchell, H.C., The Intellectual Commons: Toward an Ecology of Intellectual Property. Oxford: Lexington Books. 2005

Michael J. Sandel, Justice-What's The Rights Thing To Do? Pinguin Group, Englad, 2009

Mochtar Kusumaatmadja. Law, Society and the Founding of National Law: A description of Fundamental Idea, Pattern and Law renewal Mechanism in Indonesia, Bandung, Law and Criminology Research Institute Law faculty Unpad, 1976

Muslimin Husein, The Challenge to Pancasila as Ideology and National Principle Post Reformation, Law

${ }^{1}$ Rahmi Jened, Op. Cit, pg. 28 
Cakrawala Journal, Vol.7, No.1 June 2016, 2016

Posner Richard, Frointers of Legal Theory, Harvard University Press, 2001

Prasetyo Teguh, Constructing National Law Based on Pancasila, Law and Judicature Journal, Volume 3, Number 3 November 2014 : 213-222, 2014

Romli Atmasasmita, Integrative Legal Theory, Legal Development Theory and Progresive Legal Theory Reconstruction, Genta Publishing, Yogyakarta, 2012

Supriyanto Ari, Pancasila as Open Ideology, in Education: Article and Research Journal, 2011 